\title{
COLUMN
}

\section{The Tooth of Time: Lauge Koch's Last Lecture}

\author{
Paul F. Hoffman \\ 1216 Montrose Ave. \\ Victoria, BC, Canada, V8T 2K4
}

The Danish Greenland cartographer and geologist Lauge Koch (1892-1964) was a legend at the time of his last public appearance, in Hamilton Hall at McMaster University in March 1964. Before he was 30 years old, he had charted the entire coastline of North Greenland by dogsled (19 sheets at $1: 300 \mathrm{~K}$ scale) and had described the essential features of its geologic structure and stratigraphy (Haller 1971; Dawes 1976; Dawes and Haller 1979). This was made possible by opportunities arising from threats to Danish sovereignty over North Greenland by the United States prior to 1917 , when the American claim based on Robert E. Peary's 1891-1909 expeditions was relinquished as part of a deal whereby they acquired the Virgin Islands, formerly Danish West Indies. In 1926, Koch shifted his activities to East Greenland, where a providential Norwegian challenge to Danish sovereignty in 1931 enabled him to establish a large, international, multidisciplinary research and mapping program, utilizing ship-based float planes and flying boats for systematic aerial photography, support of land parties, and navigation through sea ice. Oskar Kulling, a member of Koch's 1929 expedition, discovered Devonian vertebrate assemblages sensationally containing the earliest known tetrapod, Icbthyostega (Jarvik 1961; Clack 2002; Larsen et al. 2008).
Supported by the Greenland Ministry of the Danish government, independent of the federal Geological Survey, Koch's East Greenland expeditions continued for twenty-three field seasons until 1958 (Koch 1961), culminating after his death with tectonic and geological maps of East Greenland (Haller 1970; Koch and Haller 1971) and the magnificent book, Geology of the East Greenland Caledonides (Haller 1971). Koch was lionized internationally-he received medals, national honours and honourary degrees in eight foreign countries and was venerated at Yale, Harvard, Columbia and McGill universities (Müller 1964; Dunbar 1966) - but in Denmark he was a controversial figure whose failure to make alliances with parties who were otherwise bound to oppose him led to a damaging court case in the mid-1930's (Ries 2002) and the premature termination of his East Greenland mappingbased research program in 1958 (Dawes 2012). Koch was 71 years old and struggling to complete a treatise on the Precambrian geology of Greenland and North America when, in February 1964, he embarked on a sixmonth lecture and study tour sponsored by the American Geological Institute and the Carlsberg Foundation. Some may read this who were present at Koch's last lecture, in Hamilton Hall, but after nearly fifty years their recollection will have faded while mine has not.

Svend Lauge Koch was born in Copenhagen in 1892, the first surviving child of parents already in their thirties, the father a clergyman and author (Dawes 2012). As a teenager, his imagination was fired by the illfated 1906-08 Danmark Expedition (Hansen 2005), during which his 'uncle' (actually a more distant relative) Captain J. P. (Johan Peter) Koch and two companions dog-sledded over $2000 \mathrm{~km}$ from Danmarkshavn to Cape Bridgman on the north coast of Greenland, previously reached only from the west (Fig. 1). Lauge Koch had his first taste of Greenland in 1913 as an apprentice to Morten P. Porsild, a Danish botanist who spent most of his adult life based at a research station he founded at Qeqertarsuaq (Godhavn), on Disko Island in central West Greenland. As a 21-year-old, Koch's interests had been split between geology and ornithology, but under the knowledgeable Porsild his assigned task to collect Tertiary plant fossils evolved into a flair for mapping and a desire to investigate the glaciology and geology of the unexplored north coast of Greenland (Dawes 2012). Late in the season, he actually met J. P. Koch and meteorologist-glaciologist Alfred Wegener at Godhavn. They were headed south after crossing the Inland Ice at its widest part, having spent the previous winter on the ice near Danmarkshavn. Before arriving in Greenland, the 33year-old Wegener had submitted the fuller version of his newly-developed theory of continental displacement to Petermann's Geographical Journal (Jacoby 2001). Koch, who had brought along the published version to read, presented it to the delighted Wegener who did not even know it had been accepted (Dawes 2012).

The west side of Greenland, although home to the largest icebergs 


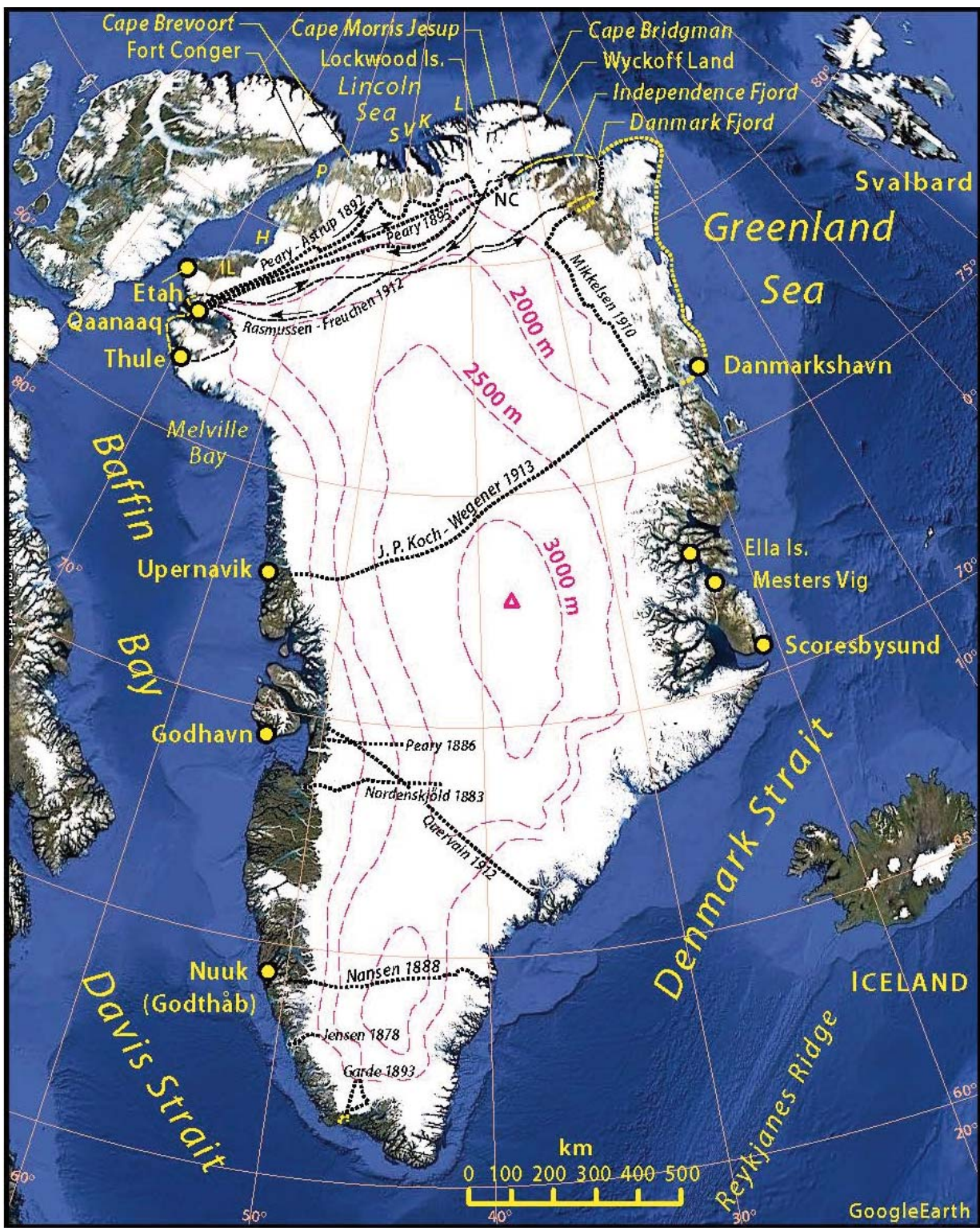

Figure 1. GoogleEarth image of Greenland and environs, showing locations mentioned in the text, contours of elevation above sea level and routes of early expeditions on the Inland Ice including Peary and Astrup 1892, Mikkelsen 1910, Rasmussen and Freuchen 1912, and J. P. Koch and Wegener 1913, according to Rasmussen (1915). Note that only contours above $1500 \mathrm{~m}$ are shown because of steep gradients at the Ice margins. Sea ice is not shown. Arctic sea ice is expelled into Greenland Sea in summer, while Denmark and Davis straits are the principal source areas of North Atlantic Deep Water. Major fjords and glaciers in North Greenland: H, Humboldt Glacier; K, J. P. Koch Fjord; L, De Long Fjord; S, Sherard Osborn Fjord; V, Victoria Fjord. Other locations: IL, Inglefield Land; NC, Navy Cliff.

outside of Antarctica, is protected from the summer flush of Arctic sea ice that makes the northeast coast of Greenland all but unserviceable by sea. Consequently, West Greenland has long been colonized while East Greenland never has, despite its proximity to Europe. The vast extent of Greenland's 'inland ice plain' and its independ- ence of mountainous topography was first appreciated by H. J. Rink, who spent 20 years in West Greenland, first as a scientist and later as a trade manager and administrator. Rink reasoned that the vast catchment area drained in West Greenland by only a small number of narrow outlet ice streams ('isströmme') requires the ice streams to be enormously thick, giving rise to giant icebergs (Rink 1853). Rink's lecture at the Royal Geographical Society (London) on the origin of giant icebergs caught the attention of Charles Lyell, who had long argued that the action of icebergs and sea ice alone could account for the enigmatic landforms and till deposits of Pleistocene ('Newer Pliocene') age (Boylan 1998). I suspect that it was Rink's assertion that giant icebergs were a product of the Inland Ice that caused Lyell in his last publications (Lyell 1863, 1865) to soften his opposition to the former existence of such ice sheets over northern Europe and North America (Agassiz 1842).

The head of Baffin Bay was explored and the channel between Ellesmere Island and Greenland revealed in stages by Edward Inglefield (Royal Navy, 1852), Elisha Kent Kane (American civilian, 1853-55), Charles Francis Hall (American civilian, 1871-73) and George S. Nares (Royal Navy, 1875-76). In 1882, two members of the Greely (United States Army) Expedition, James B. Lockwood and David L. Brainard, sledged on sea ice from Ellesmere Island along the north coast of Greenland to $40^{\circ} \mathrm{W}$ longitude (Lockwood Island), reaching a new 'farthest north' at $83^{\circ} 23^{\prime} 08^{\prime \prime} \mathrm{N}$ (Koch 1940; Hayes 2003). In 1891-92 another American, career Navy officer Robert E. Peary, established a base near Qaanaaq, north of Thule, from which he and Norwegian skier Eivind Astrup dog-sledded across the northern ramp of the Inland Ice to Navy Cliff at the head of Independence Fjord, a 2000 $\mathrm{km}$ round-trip (Peary 1893). From Navy Cliff (Fig. 2), they could see icefree land on the northern skyline (Peary Land), which Peary mistakenly inferred to be a separate island or archipelago.

Peary's attempts to reach the North Pole embarked from the Canadian side of Robeson Channel. In 1900, a year after frostbite required the amputation of all but the little toes on both his feet, Peary along with Matthew Henson and five Inuit hunters embarked from Fort Conger (Fig. 1), nearly $700 \mathrm{~km}$ north of Thule. They sledged eastward along the north coast of Greenland on the sea ice until finally with one Inuit, Angmalortooq, 


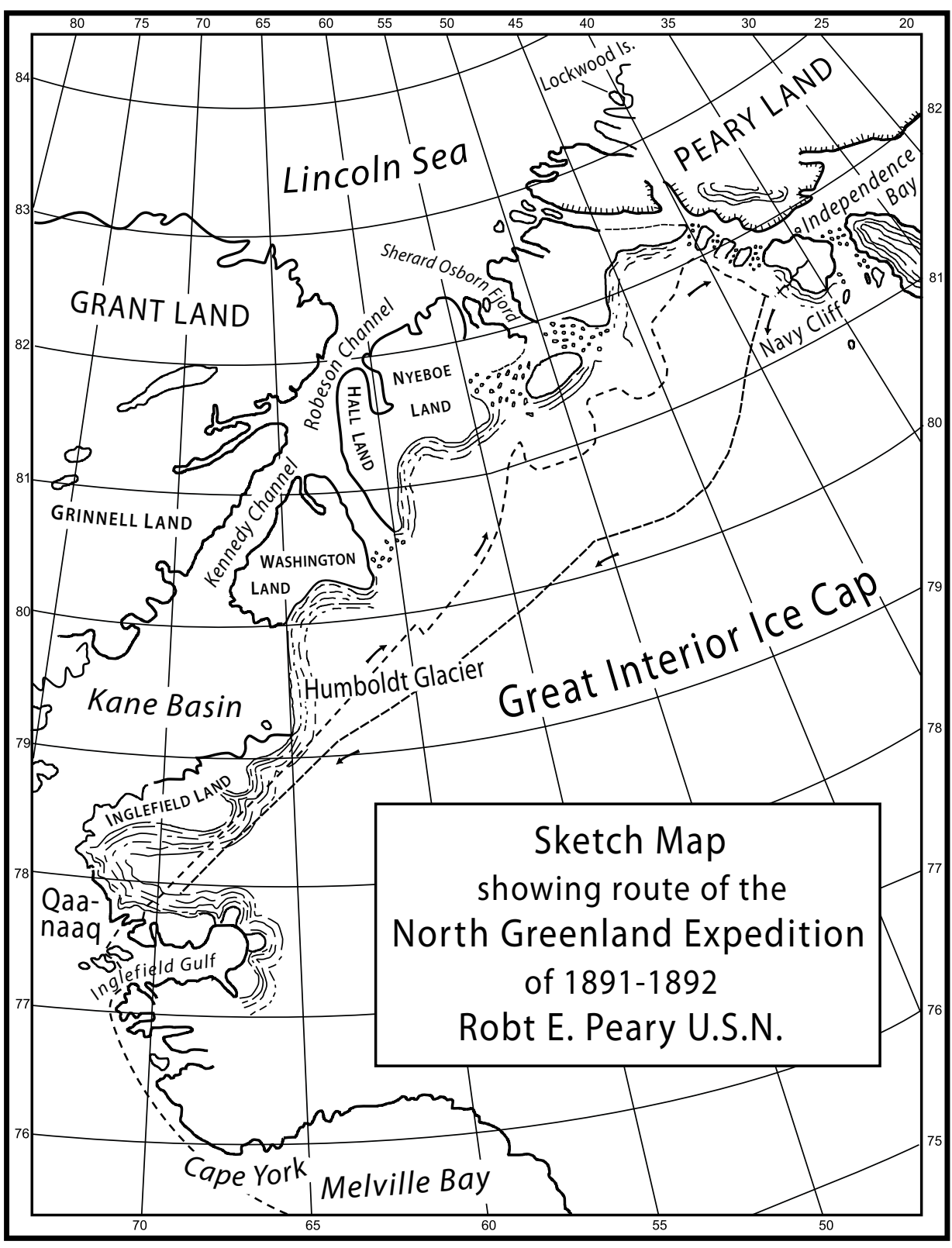

Figure 2. Route taken by Robert E. Peary and Eivind Astrup in 1892 from Redcliff House, near present Qaanaaq, across the Inland Ice to Navy Cliff, overlooking the head of Independence Fjord. From there, Peary inferred that the fjord was a bay opening eastward into the Greenland Sea (Fig. 1) with a channel (Peary Channel) leading westward into Lincoln Sea (modified from Peary 1893).

they rounded Cape Morris Jesup, the northernmost point on Greenland. After an attempt to sledge poleward was stymied by pressure ridges and water leads at $83^{\circ} 50^{\prime} \mathrm{N}$, they continued eastward another $200 \mathrm{~km}$ to Wyckoff Land (Peary 1903; Koch 1940; Mills 2003). After 1900, two Arctic myths were cast adrift: Greenland did not extend across the Pole to the New Siberian Islands and the Polar ocean was not free of ice.

A permanent trading station was established at Thule in 1910 by the Greenland-born ethnographer and anthropologist Knud Rasmussen, who embarked on a series of expeditions across North Greenland and Arctic Canada (Mathiassen 1934). After a false start in 1911, Rasmussen and junior colleague Peter Freuchen, a talented writer, crossed the Inland Ice south of Peary and Astrup's route in 1912. They reached Danmark Fjord, where MyliusErichsen, leader of the Danmark Expedition, and two companions had per- ished five years earlier. Returning by way of Independence Fjord, they found no evidence of a channel to the northwest reported by Peary (Fig. 2). They did find Mylius-Erichsen's cairns but they were empty. The notes they once contained, first reporting the non-existence of Peary's channel, had been retrieved in 1910 by Captain Ejnar Mikkelsen, who in 1912 was still ice-bound in East Greenland. His overdue return had been one of the motivations for Rasmussen and Freuchen's epic sledge journey in the first place (Koch 1925a). The journey, which nearly cost both men their lives through starvation, was described not altogether approvingly by Sir Clements Markham, President of the Royal Geographical Society (London), as "the finest ever performed by dogs" (Markham 1921).

Lauge Koch was recommended for Rasmussen's Second Thule Expedition (1916-18) by Hans Peter Steensby (Dawes 2012), an anthropologist at the University of Copenhagen where Koch had graduated in 1911 and would receive his M.Sc. (1920) and Ph.D. (1929). Originally enlisted to map the geology and assist Freuchen with the cartography, the 24-year-old Koch assumed both responsibilities when Freuchen had to attend to pressing matters in Thule. Rasmussen's ultimate objective was to map the great fjords on the Greenland side of the Lincoln Sea, including Peary Channel (Fig. 2). The original plan was to cross the Inland Ice to Independence Fjord and work westward, but in the end they crossed over into Kane Basin, took the sea ice through Kennedy and Robeson channels into the Lincoln Sea, and mapped the fjords from west to east before returning to Thule over the Inland Ice (Rasmussen 1921).

Arriving in Godthåb (Nuuk) by ship in April 1916, Rasmussen and Koch made the punishing 2000-km journey up the west coast to Thule by mid-summer, mapping the ice-clogged Melville Bay as they went. Then they relayed supplies onto the Inland Ice for the following year. The unexpected arrival of the old expedition ship Danmark and her crew at Thule late in the season required Koch to spend the winter at Tasiusak, near Upernavik, separated from Rasmussen. When he returned to 
Thule, two men from the Danmark had talked their way onto the northern party. Neither Hendrik Olsen, a Greenlander and veteran of the Danmark Expedition, or Thorild Wulff, a 40-yearold Swedish botanist, would survive the journey.

As the party would rely on hunting to feed the dogs and the men when not on the Inland Ice (where game is non-existent), three Inuit hunters joined Olsen and the three scientists. Aside from Rasmussen, as chief, the six others were explicitly given equal status. Departing in early April 1917, the party made good time and arrived at Dragon Point (Fig. 3), between Saint George and Sherard Osborn fjords, in mid-May. For the next six weeks they explored the main fjords to the east-Sherard Osborn Fjord, Victoria Fjord, Nordenskjöld Fjord, and newly discovered J. P. Koch Fjord and De Long Fjord (Rasmussen 1927; Koch 1940). The work was exhausting as deep snow covered the sea ice in the protected fjords. Worse, hunting was less productive than predicted with the result that everyone was always hungry and the number of dogs was in steep decline. Deciding to forego a final dash to Cape Morris Jesup, they headed back toward Dragon Point and their planned ascent onto the Inland Ice at the head of Saint George Fjord. Melting snow and meltwater made travel arduous and slow. On July 21st, Hendrik Olsen did not return from a hunting excursion and could not be found. The remaining six finally reached Saint George Fjord in early August, but rotten sea ice forced them onto land $20 \mathrm{~km}$ short of the head of the fjord and $70 \mathrm{~km}$ from the edge of the Inland Ice (Fig. 3). After crossing the Daniel Bruun Ice Cap, the party had to drag their sledges through a snowless limestone canyon to the Rink Ice Cap, and then across a 20$\mathrm{km}$-wide valley (Midgaardsormen) of bare ground to the foot of the Inland Ice. This took five days of toil.

Driven by desperation, they made good time on the Inland Ice until they reached the broad Humboldt Glacier, where they were slowed to a crawl by rivers of supraglacial meltwater. Out of food and dogs, they descended from the Inland Ice on August 24th near Cape Agassiz in

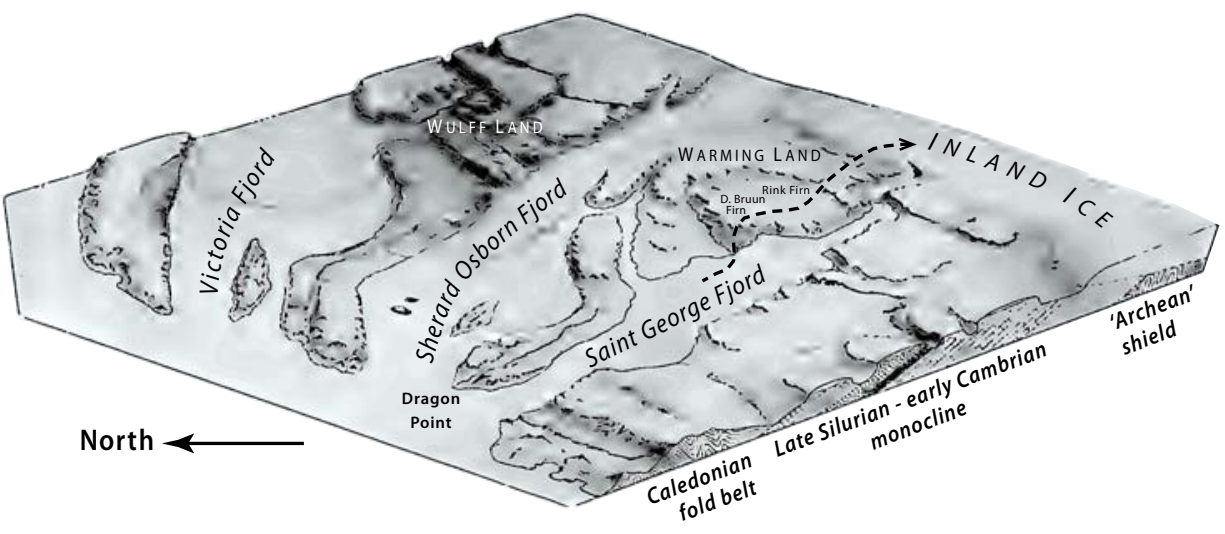

Figure 3. Block diagram of fjords on the North Greenland side of Lincoln Sea, showing Dragon Point, a rendezvous used in 1917 during the 2nd Thule Expedition, and the route taken out of Saint George Fjord across the Daniel Bruun and Rink ice caps onto the Inland Ice. Note the geological cross-section drawn by Lauge Koch (modified from Rasmussen 1921).

westernmost Inglefield Land (Fig. 2). They were still $225 \mathrm{~km}$ from Etah, the nearest settlement, and Wulff in particular was near the end of his rope. Rasmussen and Ajako, the strongest Inuit, set out immediately on a forced march to Etah for help. Koch and the other two Inuit were left to slowly ease Wulff toward a large lake that drains into Marshall Bay. However, Wulff soon refused to go on and the other three, in dire shape themselves, decided to proceed without him. They were met by a relief party from Etah on the 4th of September.

In Etah, Rasmussen and Koch differed about the need to mount an immediate search for Wulff's body: fresh snow and dim light would make it difficult if not impossible to relocate his final resting spot. They differed about how best to handle the negative reaction of their backers and the press. Koch's letters (Dawes 2012) reveal that Wulff was suffering from advanced syphilis and had been taking morphine throughout the journey for pain and depression. Koch felt drained by Wulff's self-pity and need for constant encouragement. The expectations of the expedition had been unrealistic but Wulff should not have been on the party in the first place. The shock of the human tragedies was compounded by a public relations nightmare. Rasmussen and Koch also disagreed about an impending police inquiry: should it be held in Greenland (Rasmussen) or Copenhagen (Koch, supposedly on the advice of Porsild)? In the end, their reputations survived the ordeal but their friendship did not. Koch vowed that on subsequent expeditions, he would be in charge.

Koch shrewdly named his own 1920-23 expedition to North Greenland the Bicentenary Jubilee Expedition, to celebrate the arrival in Greenland 200 years earlier of Hans Egede and company (Koch 1919), which reestablished Dano-Norwegian contact with the Norse settlers. During the three-year expedition, Koch wintered at Upernavik and set up seasonal headquarters near Qaanaaq. He originally intended a sizeable expedition utilizing tracked vehicles (a product of the European Trench War of 1914-18) to transport supplies across the Inland Ice. In the end, he opted to use Peary's old base at Fort Conger on the north side of Robeson Channel as the jumping off point in 1921 for the first circum-navigation of Peary Land (Koch 1923a, 1927, 1929c, 1940; Mills 2003). After improving his previous mapping with Rasmussen as far east as De Long Fjord, Koch and three Inuit companions including two hunters then mapped the entire north coast of Peary Land, becoming the first Dane to visit Peary's cairn at Cape Morris Jesup. Beyond it, at Cape Bridgman, they found another cairn with a message left by J. P. Koch of the Danmark. Expedition fourteen years earlier.

After limited hunting success around the low eastern cape of Peary Land (Horlufsholm Strand), they entered Independence Fjord and on its 


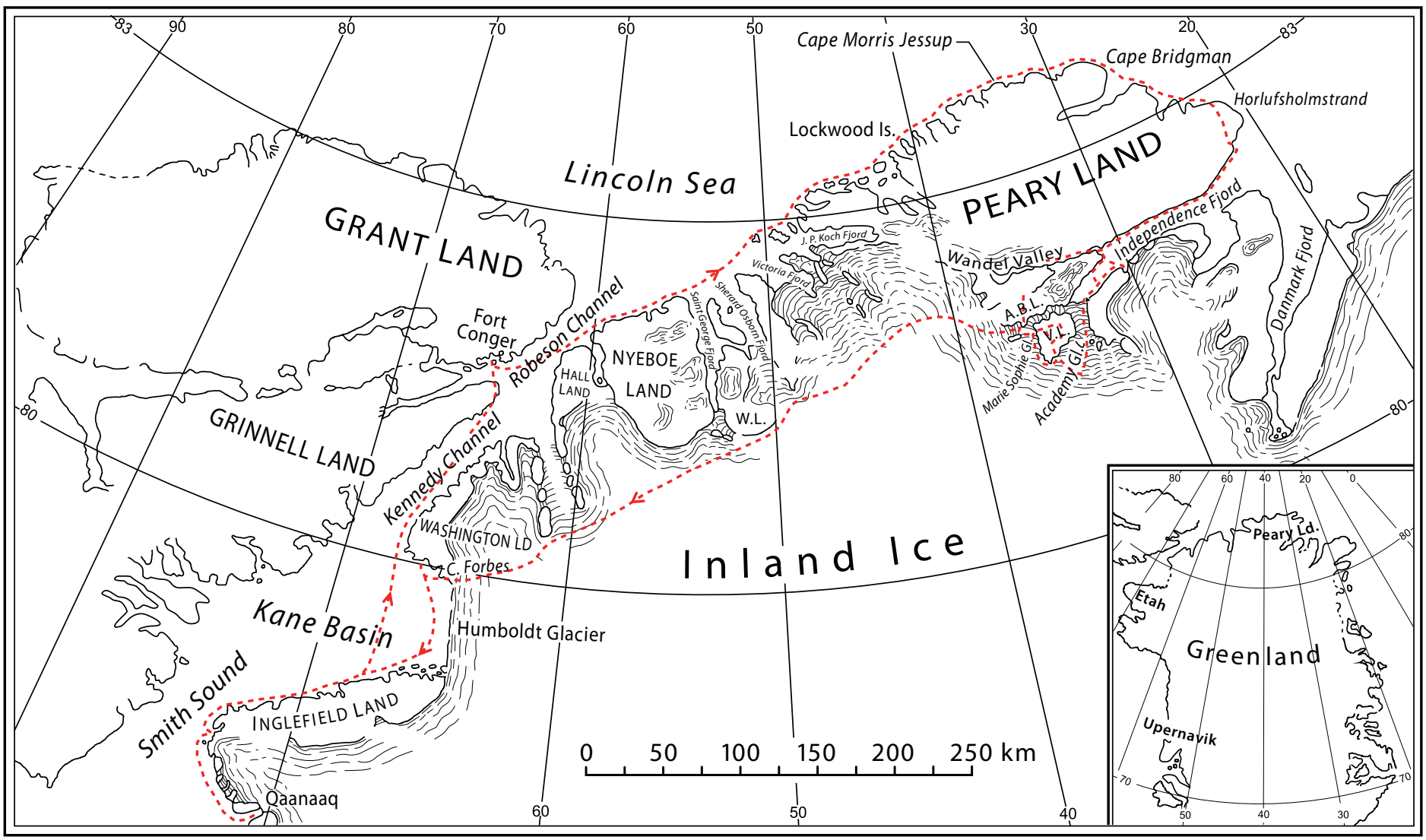

Figure 4. North Greenland and adjacent Canada showing the route (dashed red line) taken by Lauge Koch in 1921 during the Bicentenary Jubilee Expedition (modified from Koch 1924). The sledge journey with three Innuit companions covered $2400 \mathrm{~km}$ in 200 days, during which Koch mapped the topography and the geology. Abbreviated locations: A.B.L., Adam Biering Land; V.L., Vildtland (Navy Cliff); W.L., Warmland.

north shore found a broad low valley (Wandel Valley) heading off to the west (Fig. 4). They walked $35 \mathrm{~km}$ up this linear valley to a lookout, from where they could see a chain of lakes with no end in sight (Koch 1925a, 1940). Had they walked on the other (south) side of the river they would have passed outcrops of Cryogenian tillite (Morænesø Formation) along the valley floor (Jepsen 1971; Dawes 1976; Bengaard and Henriksen 1986). Returning to Independence Fjord, they found a cairn near its head (at Cape Glacier) with a note left by MyliusErichsen reporting a glacier (Marie Sophie Glacier) entering from the west where Peary Channel should have been (Fig. 2). They ascended the Academy Glacier out of the fjord and mapped the Vildtland nunataks at the edge of the Inland Ice, which are composed of flat-lying sandstone invaded by feeders to the stratigraphically overlying ZigZag Dal Basalt Formation, the outpourings of a large igneous event at $\sim 1382 \mathrm{Ma}$ (Upton et al. 2005). After stopping at Peary's 1891 observation point near Navy Cliff, they retraced his outgoing route (Fig. 2) from which they could see the Wandel Valley again and its chain of lakes, from a lofty perspective. Only then did they circle back along the northern rim of the Inland Ice (Fig. 4). Expecting a supply depot en route that did not materialize, they barely made it to Cape Forbes on the north side of the Humboldt Glacier, where a hunting party was waiting as planned in case it was needed. To avoid the river crossings on the Humboldt Glacier, Koch waited until freeze-up in late September before returning on the new sea ice to his headquarters near Qaanaaq. They had sledged $2400 \mathrm{~km}$ in 200 days on short rations.

In the wake of the MyliusErichsen tragedy, much had been made of the non-existence of Peary Channel and, more critically, Peary's incorrect inference that Independence Fjord was a bay that opened southeastward into the Greenland Sea (compare Figs. 1 and 2). Koch immediately endeavoured to set the record straight (Koch 1923a, 1924, 1925a), with Morten Porsild serving as editor and correspondent with the outside world. Koch praised Peary's observations and observed that from Peary's vantage points on the Inland Ice and Navy Cliff, he had good reason to infer that Wandel Valley was a frozen arm of the sea. Besides, he concluded, not so long ago Peary Land was a true archipelago as the land has been steadily rising since the last glacial period (Koch 1925a).

In the Spring of 1922, Koch returned with three Inuit to the Lincoln Sea (Koch 1927, 1929c, 1940). Mapping the coasts of Washington Land and Hall Land, they linked up with the previous year's outgoing route from Fort Conger at Cape Brevoort, the western tip of Nyeboe Land. In midsummer, Koch studied the gently seaward-tilted Early Paleozoic limestone succession (Fig. 3) on the south shore of Washington Land (Koch 1929a), and back-hauled fossil collec- 


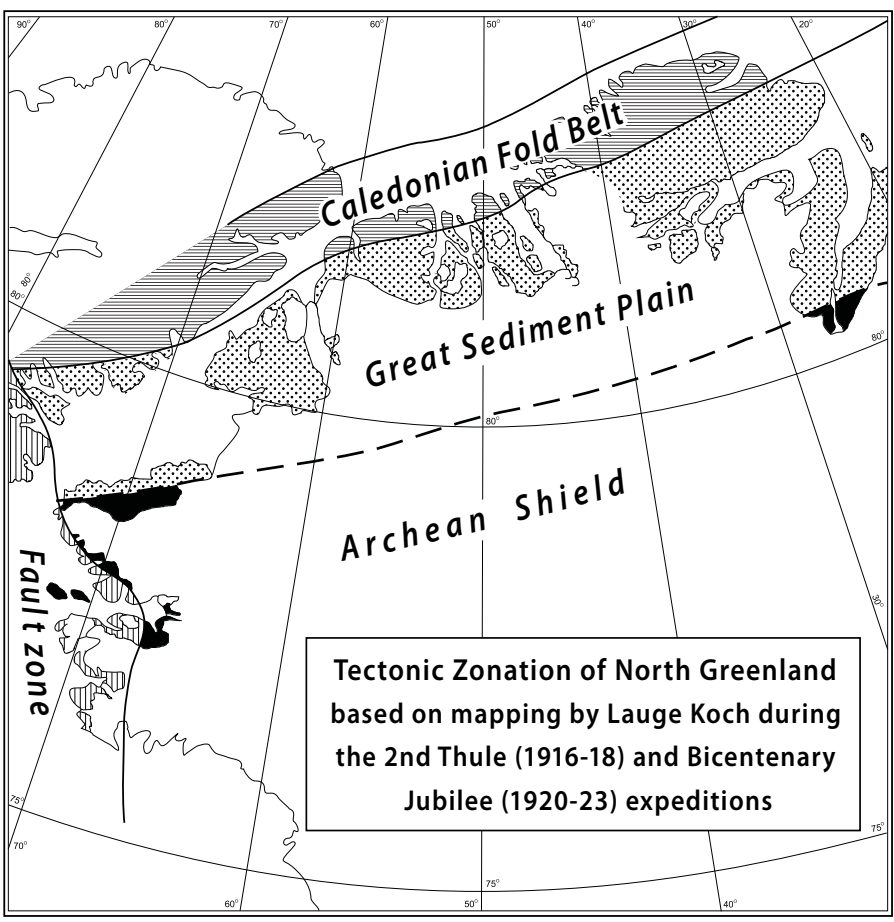

Figure 5. Tectonic zonation of North Greenland into an 'Archean' shield, a Paleozoic platform ('Great Sediment Plain'), a Caledonian fold belt, and a fault zone along the coast of Baffin Bay (modified from Koch 1925). The apparent left-lateral offset of the Caledonian fold belt across Nares Strait between North Greenland and Ellesmere Island (Canada), disputed by Koch and many subsequent workers, was cited by Wegener (1924) in support of Taylor's (1910) interpretation (Fig. 6) of an early Tertiary rift origin of Baffin Bay.

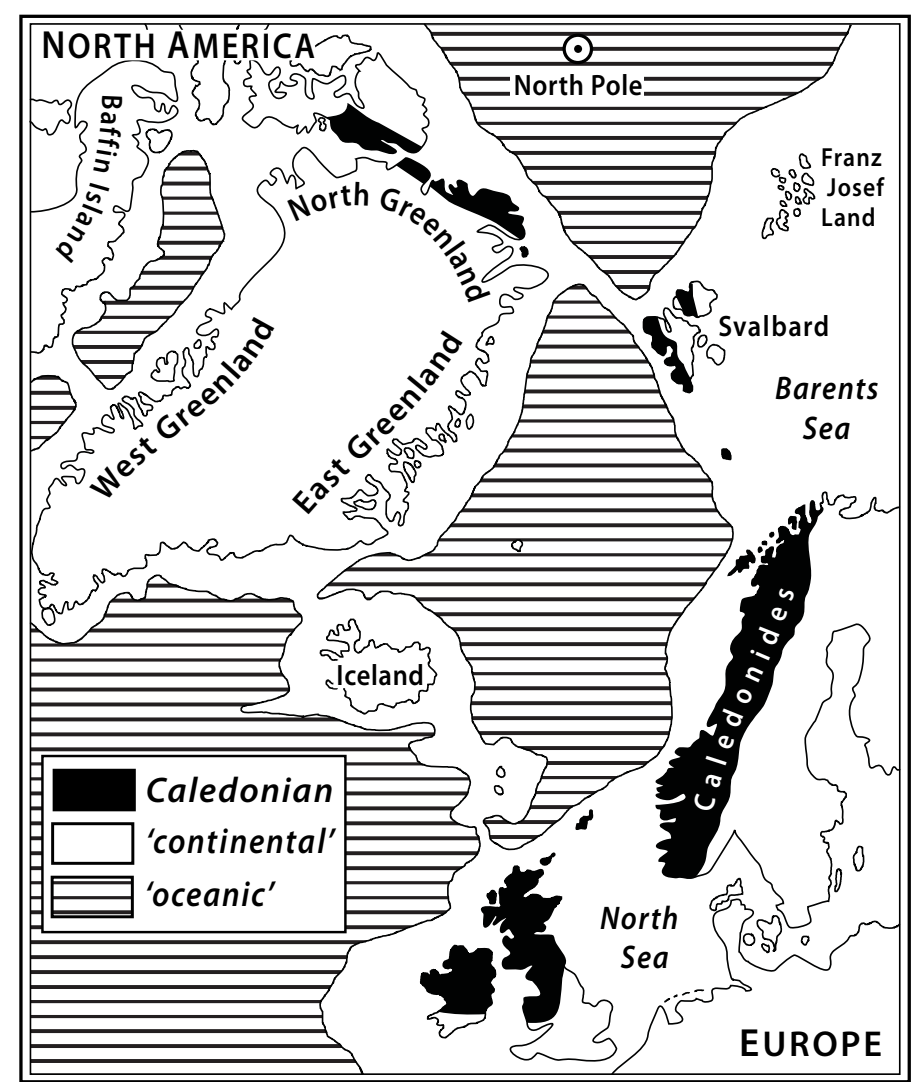

Figure 6. The Caledonian fold belt of North Greenland and Ellesmere Island (black areas) and its inferred continuation with contemporaneous orogenic belts in Svalbard, western Norway and northwest Britain (modified from Koch 1920). tions. In the Fall, he crossed the Inland Ice lobe with a Dane and two Inuit to map and collect fossils from the base of the Paleozoic succession on Inglefield Land. The following Spring, he returned from Upernavik and mapped the Cape York district, including the Proterozoic Thule Supergroup, before his Bicentenary Expedition ended in mid-1923. The unqualified success of the expedition drew attention to its then 31-year-old leader.

The combined results of the 1916-18 expedition with Rasmussen and his own of 1920-23 enabled Koch to compile the first systematic topographic (Koch 1922, 1932) and geological (Koch 1929a, 1933; Dawes and Haller 1979) maps of North Greenland. Geologically, he divided the region into three zones (Fig. 5): a southern 'Archean' shield area (largely ice covered) with an inferred downfaulted block bordering Baffin Bay, where a thick 'Algonkian' (Meso-Neo- proterozoic) cover sequence (Thule Supergroup of Dawes 1997, 2006a) is preserved; a Paleozoic platform ('Great Sediment Plain') in which Proterozoic cover is overlain by nearly $4.0 \mathrm{~km}$ of slightly-tilted, seaward-younging, early Cambrian (Atdabanian) through late Silurian (Ludlow) fossiliferous carbonates with abrupt terminal drowning (Dawes 2004); and a northern belt of 'Caledonian' folding and faulting (Koch 1920, 1921, 1927, 1929c, 1935, 1940). The area is covered by four sheets of the modern Geological Survey of Greenland 1:500K map series, Thule (Dawes 2006b), Humboldt Gletscher (Dawes and Garde 2004), Nyeboe Land (Henriksen 1989) and Peary Land (Bengaard and Henriksen 1986). Koch's major reports appeared domestically in the Meddelelser om Gronland but he took care to publish summary papers in England (Koch 1923a, 1924) and America (Koch 1923b, c, 1925a, b). He viewed the Caledonian fold belt in
North Greenland as being collinear with contemporaneous 'geosynclines' in Arctic Canada and northwestern Europe (Fig. 6).

Koch was aware of the intense ongoing debate over the theory of continental drift (Dawes 2012). He affirmed that faunal evidence in North and East Greenland is "highly confirmato$r y$ " of paleoequatorial migrations as inferred by Köppen and Wegener (1924), and he agreed that a Paleozoic or older origin for Baffin Bay is not supported by the regional stratigraphy. However, he questioned Taylor's (1910) interpretation of Nares Strait as a (transform) fault zone related to Tertiary opening of Baffin Bay (Fig. 7), and he objected to Wegener's (1924) citation of his own map (Fig. 5) in support of that interpretation (Koch 1929c). He argued against major strikeslip in Nares Strait until the end (Koch 1963), as do others (Christie et al 1981; Dawes 2009) who leave themselves no 


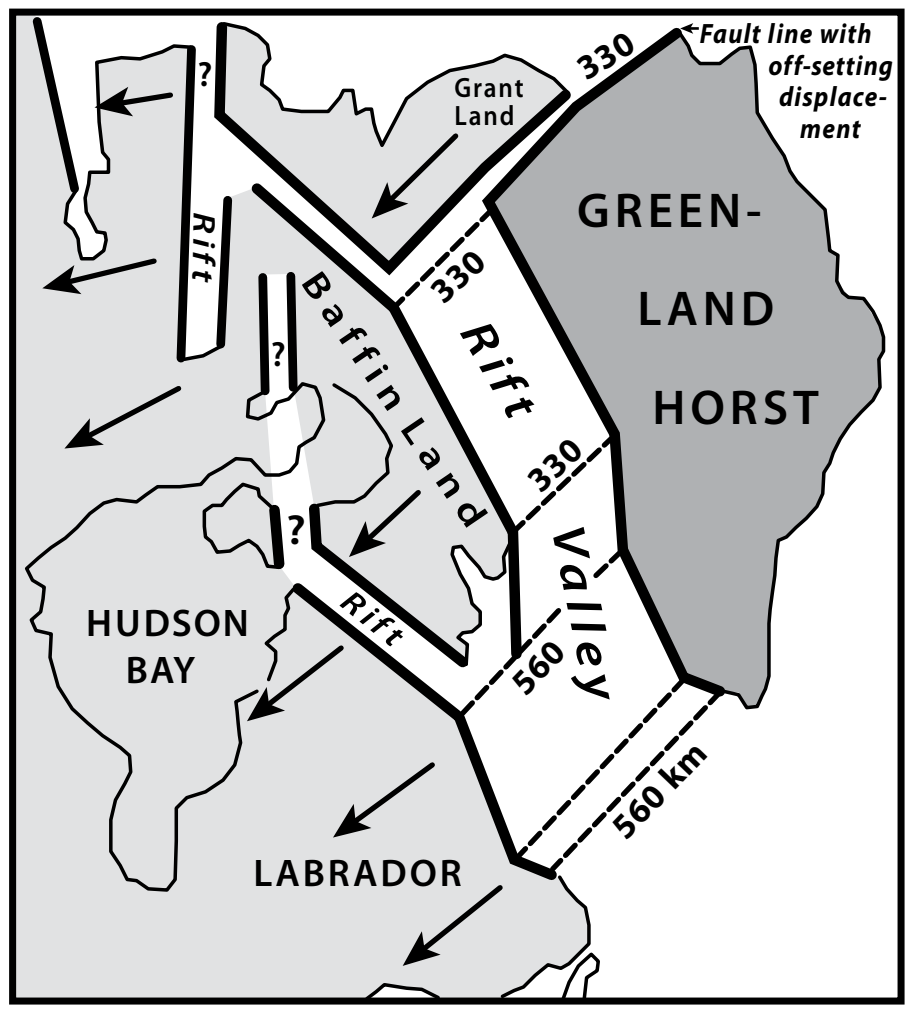

Figure 7. Interpretation of a fixed Greenland with Tertiary separation of North America by southwestward drift (redrawn from Taylor 1910). To account for the greater width of Davis Strait relative to Baffin Bay, Taylor postulated a branch rift in Hudson Strait - Foxe Basin (between Baffin Island and mainland North America). Alternatively, if no oceanic rift exists in this branch, Greenland must have rotated anticlockwise with respect to North America about an Euler pole in Arctic Canada.

explanation for Baffin Bay, but he claimed to be agnostic about continental drift more generally: "... to the theory as a whole no attitude will be taken here" (Koch 1963). Koch's reaction to continental drift was that of a parochialist: does the concept work in my field area? He did not engage the broader tapestry of the debate. Moreover, Koch was a master of facts, not of synthesis. Yet, in a rare speculative moment he mused that "future investigations will reveal strong faulting north of Baffin Bay, which faulting has possibly some connection with the development of Davis Strait - Baffin Bay" (Koch 1929c, p. 319).

Indeed it would. The oceanic width of Davis Strait is nearly twice that of Baffin Bay. Taylor (1910) accounted for this with an oceanic branch rift between Baffin Island and mainland Canada (Fig. 7). Conversely, if no oceanic rift exists there, then the widening southward of Davis Strait -
Baffin Bay requires an anticlockwise rotation of Greenland with respect to interior North America about an Euler pole in Arctic Canada. The Paleogene Eurekan orogeny in the Sverdrup Basin north of Baffin Bay and in Nares Strait itself is a transpressional manifestation of this rotation (Miall 1983; De Paor et al. 1989; Okulitch et al. 1990; Tessensohn et al. 2006, 2008; von Gosen et al. 2008; Denyszyn et al. 2009). Paleogene deformation also extends eastward within the 'Caledonian fold belt' of North Greenland (Lyberis and Manby 1999), merging ultimately with the Nansen Fracture Zone between Greenland and the Bar- ents Sea shelf of Arctic Europe.

After the Bicentenary Expedition, Koch switched his main focus to East Greenland, where he led a twoyear expedition (1926-27) supported by the three-master Gustav Holm, with headquarters at the settlement of Scoresbysund (Fig. 8). The goal was to investigate the deeply indented and geologically unexplored 'fjord zone' $\left(72^{\circ}-76^{\circ} \mathrm{N}\right)$ to the north, as well as 
the nearby Mesozoic basin in Jameson Land (Koch 1929b, 1930; Haller 1971; Birkelund and Perch-Nielsen 1976; Escher and Watt 1976; Henriksen 1997, 2008; Escher 2001; Brooks 2008, 2009; Higgins et al. 2008). The other expedition members were paleobotanist Tom Harris from Cambridge University, vertebrate paleontologist Alfred Rosenkrantz from the University of Copenhagen, and two Greenlanders, Tobias Gabrielsen and Karl Mathiassen, who would accompany Koch on the long sledge journeys (Koch 1930). The first Fall they reconnoitered as far north as Mackenzie Bay and the following Spring they sledged all the way to Danmarkshavn and back, both times exploring the cavernous fjords that transect the largely ice-free coastal mountains (Fig. 8). An overall seaward-younging succession of sedimentary rocks, tectonically overlying an 'Archean' basement complex, is majestically displayed on fjord walls up to 2000 m high (Koch 1928, 1929b, c, 1955; Haller 1971). The sedimentary stack begins with a $13-\mathrm{km}$-thick multicoloured succession of mixed clastics and carbonates of 'Algonkian' (early Neoproterozoic) age, the Eleonore Bay Supergroup (Katz 1961; Bengaard 1992; Sønderholm and Tirsgaard 1993; Tirsgaard and Sønderholm 1997; Sønderholm et al. 2008). It is followed by a recessive interval (Tillite Group) with a pair of Cryogenian glacial formations (Hambrey and Spencer 1987). The weakly metamorphosed Neoproterozoic succession is overlain by nearly 3 $\mathrm{km}$ of Cambrian and Ordovician carbonates, mostly limestone (Cowie and Adams 1957; Smith and Rasmussen 2008). An angular unconformity separates the mainly marine Neoproterozoic and early Paleozoic strata from terrestrial redbeds, including coarsegrained conglomerates, of Devonian age (Larsen and Bengaard 1991; Hartz 2000; Larsen et al. 2008). Still younger rocks occur along the outer coast, including outliers of the great Paleogene igneous province south of Scoresby Sound (Noe-Nygaard 1976). Koch (1929c) interpreted the Caledonian deformation in East Greenland as a separate belt that joined the North Greenland - European Caledonian belt at a vertex off the northeast corner of Greenland (Fig. 9).

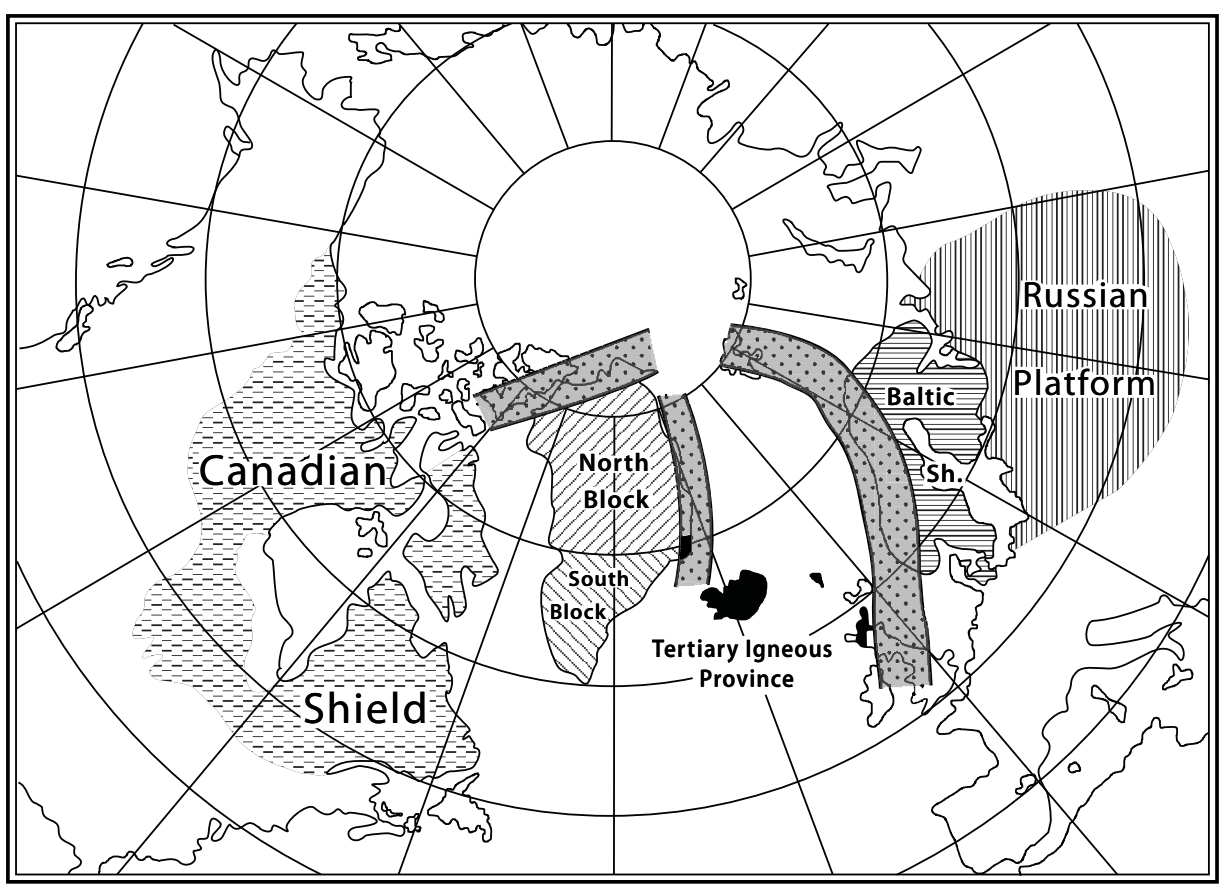

Figure 9. Koch's (1929c) interpretation of shields and 'geosynclines' (shaded dotted areas) around the North Atlantic region (compare with Fig. 5). He interpreted the Caledonian fold belt (geosyncline) of East Greenland as independent of the contemporaneous belt passing through North Greenland and northwest Europe, the two meeting at a vertex off the northeast corner of Greenland (redrawn from Koch 1929c).

The Norwegian challenge to Danish sovereignty in the region, based on intermittent occupation of long houses built by Norwegian fishermen, was taken more seriously in Copenhagen than the earlier American challenge in North Greenland. A formal challenge was issued in 1931 and was finally overruled in Denmark's favour at The Hague in 1933. The sovereignty issue was a bonanza for Koch, whose ongoing field work in the area was a determining factor in the court decision and who took full advantage of the opportunity for greatly increased private and public support for work in this logistically challenged geological paradise. With primary backing from the Greenland Administration of the federal government, Koch established permanent 'Expedition Houses' in the fjord zone (Fig. 8), accommodating over 100 scientists in total-geologists, geographers, biologists and anthropologists-during the summer season. Small labs were maintained throughout the year, avoiding the need to send all samples to Copenhagen. Starting in 1932, the camps were serviced by one or two ships (Godthaab and Gustav
Holm), attended by float planes and flying boats (Catalinas) used for systematic photogrammetric surveys, supplying land parties and aerial reconnaissance. Among the float planes was the Norseman, a wooden-bodied predecessor of the De Haviland Beaver and the first plane in which I ever flew. Operations were coordinated by wireless. When the Danish Sirius Patrol gave us permission to use Koch's Expedition House on Ella Island (Figs. 10-11), I slept in the radio room amongst stacks of wireless sets the size of beer crates, containing rows of glass tubes and enormous tuning dials. For traditionalists of the 'Heroic Era' of Arctic exploration and science, Koch's reliance on aircraft and air photo interpretation was considered a form of cheating; glorifying it (Fig. 12) was beyond detestable (Ries 2002). Understandably, Koch's ascendancy in East Greenland was viewed with increasing alarm by the institutions actually authorized to conduct geological investigations in Greenland, the Mineralogical Museum (University of Copenhagen) and the Geological Survey of Denmark. In 1931, Koch had moved 


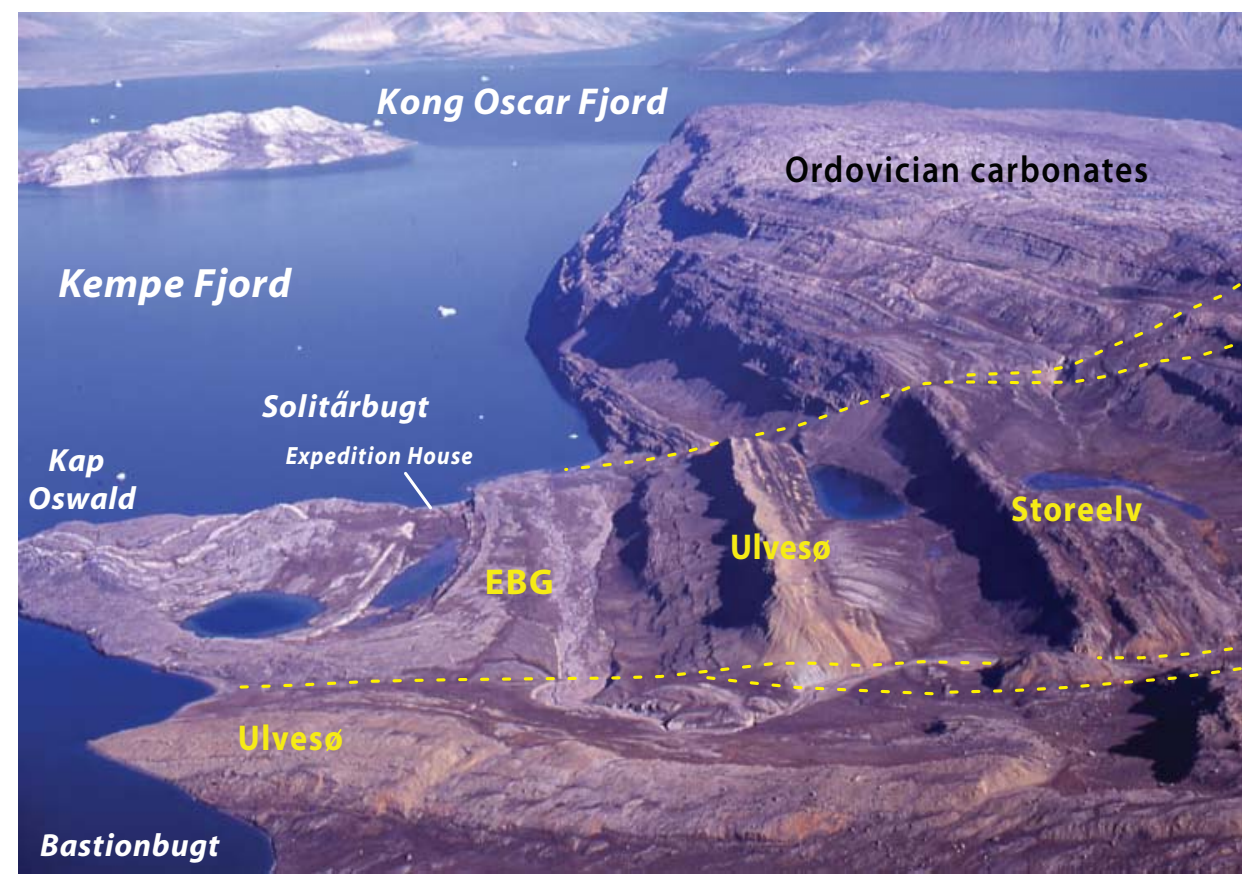

Figure 10. View from Bastion Peak (Devonian redbeds) on Ella Island: the Cryogenian Tillite Group with its pair of glacial formations (Ulvesø and Storeelv) overlies early Neoproterozoic carbonates of the upper Eleonore Bay Supergroup (EBG) and is faulted against Ordovician carbonates in the background. The Expedition House in Solitærbugt (Fig. 11) was the only one maintained after the 1930's.

his office from the Mineralogical Museum to the Greenland Administration building, and thereafter Koch was rubbing elbows with Danish bureaucrats and diplomats, not Danish geologists.

Knud Rasmussen, meanwhile, who personified the Heroic Era on account of his many ethnographic expeditions in North Greenland and Arctic Canada, had become a national icon by the time of his unexpected death at the age of 54 in December 1933. His many books and magazine articles, along with those of his friend
Peter Freuchen, endeared him to readers in Denmark and around the world. Koch was asked to write a memorial essay for a Danish newspaper, the kind of request he was incapable of refusing but one which he would have been wiser to decline (Dawes 2012).

Although laudatory in the main, Koch could not resist giving his opinion that Rasmussen's anthropology relied too much on the imagination and not enough on hard facts. Whatever the truth in Koch's statement, its timing was thoughtless and the ensuing furore brought down a hail of criticism upon

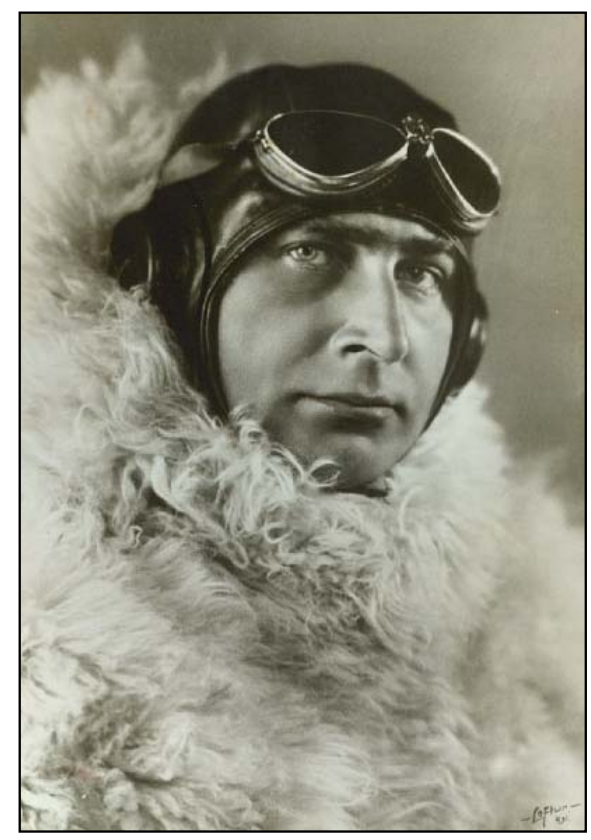

Figure 12. Publicity photo of Lauge Koch in 1938, at the time of a ballyhooed flight in search of non-existent land between East Greenland and Svalbard (reproduced in Ries 2002).

Koch. Many were not displeased to see his wings clipped.

At the time of Rasmussen's death, Koch was working on another project that would bring him more serious trouble (Ries 2002; Dawes 2012). He had been invited to write a book in German, Geologie von Grönland, as part of the series Geologie der Erde. The publishers were looking for a comprehensive review and synthesis of Greenland geology, and Koch was the logical person to ask given his extensive field experience and comparative youth. What Koch delivered, however, was an account of the geology from
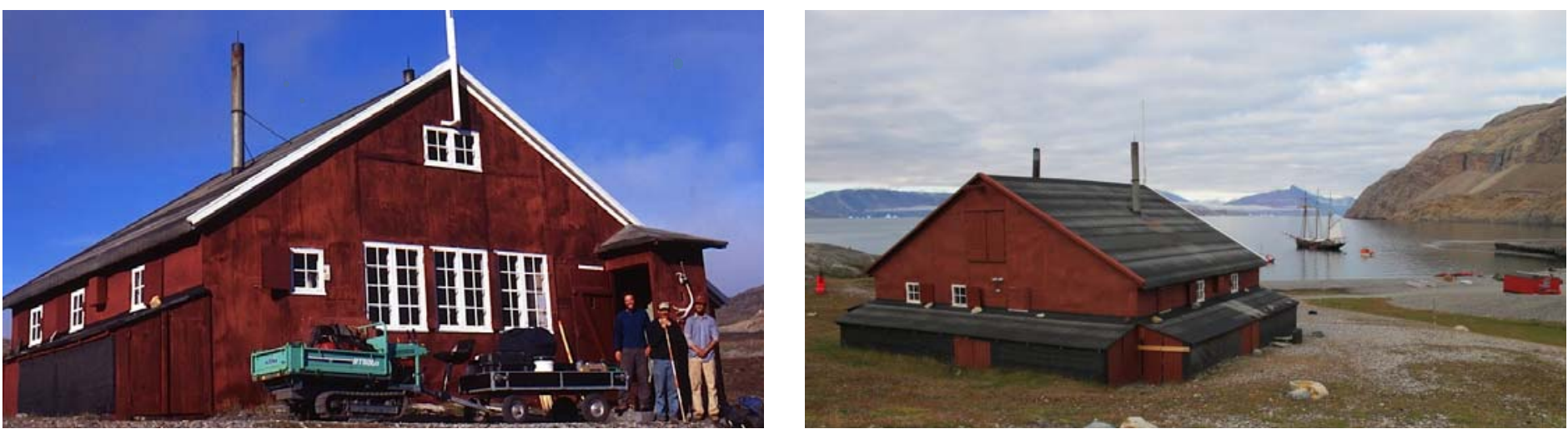

Figure 11. Lauge Koch's Expedition House on Ella Island in the fjord zone of central East Greenland in 2004, with (left photo) Adam Maloof (Princeton University), Eugene Domack (Hamilton College) and Galen Halverson (McGill University) from left to right. 
his own expeditions in North and East Greenland, with scant attention paid to the deservedly well-known Archean and intrusive igneous rocks of West and South Greenland (Hobbs 1936). He suggested provocatively that the Precambrian shield of Greenland developed independently from the Canadian Shield. Drafts of the book had not been circulated by Koch for comments before publication. An organized response came in the form of an essay review of Koch's book (Bøggild et al. 1935), submitted to the Bulletin of the Geological Society of Denmark in November 1935. The authors were eleven of the leading geologists in Denmark, including O. B. Bøggild (Director of the Mineralogical Museum and Professor of the Geological Institute, University of Copenhagen) and Victor Madsen (Director of the Geological Survey of Denmark), as well as four who had worked with Koch in Greenland. They also called for an extraordinary meeting of the Geological Society to discuss Koch's removal from membership. The book review accused Koch of 'unreliable working methods' (mapping from sea ice and the use of aircraft), 'omissions in coverage' (lack of 'Archæan' and Quaternary sections), 'unwarranted age designations' (inferring that the Eleonore Bay Group of East Greenland is younger than the Thule Supergroup of North Greenland, subsequently shown to be true), 'incorrect citations' (regarding the age of deformation in East Greenland), 'appropriation of other Explorers' results' (concerning the discovery of the 'Caledonian' fold belt of North Greenland), 'absurdities and self-contradictions' (Permian or Triassic fossils, Cambrian or pre-Cambrian tillites) and so on. The complaint over coverage is valid, but the pettiness of the review in substance reveals an antipathy toward Koch that ran far deeper than Geologie von Grönland. "Though some of their statements seem to be verified as regards details," wrote another reviewer (Hobbs 1936), "others are trivial, and they are made in a particularly bad spirit, marked by an entire failure to recognize the importance of the larger results [of Koch's work]". The poisonous book review (Bøggild et al. 1935) was published in three languages (Danish, English and German) and 600 reprints of the English version were distributed around the world. With the backing of the Greenland Administration, Koch sued the 'Eleven' for libel, prompting an eloquent letter of support from an unlikely source, Rasmussen's protégé Peter Freuchen (Ries 2002). The court ruled in favour of the Eleven in March 1937, assessing costs to Koch but expressing reservation about its own competence on the scientific questions. Fearing the loss of a field season, Koch resisted until the last allowable day the advice of his lawyers and the Greenland Administration to appeal the court decision. When the High Court finally decided in late June 1938, they upheld the lower court finding that the book review was not libellous, but ruled that the attempt to have Koch removed from membership in the Geological Society was excessive. Costs were assigned such that both parties (in fact different branches of one government) paid equally for both proceedings (Ries 2002). Some saw wisdom in the High Court decision: purely scientific disputes have no place in courts of law. For Koch it was a personal disaster. His desire, one assumes, to replace the retiring Madsen as Director of the Geological Survey and eventually assume the professorship at the University of Copenhagen was shattered. By choice or necessity, Koch would thereafter work mainly with non-Danish geologists.

Denmark was under military occupation by Germany from 1940 until 1945. Geological work in Greenland was suspended. After the war and still employed on a year-to-year basis as a consultant to the Greenland Administration, Koch slowly reestablished his East Greenland field program, relying on the post-war boom in mineral exploration (Cowie 1959; Koch 1961; Haller 1971; Dawes 2012). His efforts were rewarded during the party's second post-war field season in 1948, with the discovery of a significant lead-zinc deposit at Mesters Vig (Fig. 8), on the south side of King Oscar Fjord. The construction of an airstrip at Mesters Vig greatly simplified access to and within the fjord zone. Crews could be flown not shipped to Greenland and only one of the pre-war Expedition Houses, Ella Island, was reestablished.
With better aircraft and eventually helicopters, systematic 1:250K geological mapping was undertaken between $72^{\circ}$ and $76^{\circ} \mathrm{N}$ (Haller 1971; Koch and Haller 1971). More and more, the actual mapping and compilation were done by the Swiss structural geologist John Haller at the University of Basel (from 1965 at Harvard University). This left Koch open to a new line of attack: outsourcing the acquisition of strategic information. For years an uneasy truce had existed between Koch and the Geological Survey of Greenland, founded in 1946 with authority over all of Greenland but effectively excluded from East Greenland. Following the 1958 field season, Koch's field program was abruptly terminated by the Greenland Administration. Mapping north of $72^{\circ} \mathrm{N}$ was complete and on schedule, but the planned four additional field seasons needed to complete the mapping south to Scoresby Sound at $70^{\circ} \mathrm{N}$, which would have coincided with Koch's retirement in 1962, were not funded. Ironically, there is evidence to suggest that the proximal cause of the cancellation was an urgent need to fund exploratory drilling, in the hopes of attracting international investors, at a molybdenum deposit (Malmbjerg) near Mesters Vig found on Koch's 1954 expedition (Dawes 2012).

Koch's research program ended just as the plate tectonic revolution was getting underway, with the paleomagnetic confirmation of continental drift (Frankel 2012). Koch did not live to see its acceptance but John Haller (1927-1984) did, without his endorsement. In the early days of plate tectonics, mountain building (orogenesis) was assumed to result from subhorizontal shortening of the crust during collision or subduction-accretion. In the East Greenland Caledonides, Haller observed a three-layered crustal structure, a deep structural level below ('infrastructure') and a shallow structural level above ('superstructure'), juxtaposed across a warped 'zone of disharmonic detachment (Haller 1971, p. 144-149). The implied tectonic shortening direction is subvertical, not subhorizontal. If the crust was thinned yet is of normal thickness today, it was either thickened again after being thinned or was thicker than normal before being thinned. Orogenic collapse, the thinning of tec- 
tonically overthickened crust, is a logical inference from East Greenland structure, when viewed as being adjacent to the great thrust nappes of western Norway and in the context of Caledonian collision between Baltica and Laurentia (McClay et al. 1986; Hartz and Andresen 1995; Torsvik 1998; Hartz et al. 2001; Gilotti and McClelland 2008; Henriksen and Higgins 2008; Cocks and Torsvik 2011). The idea of 'nappe tectonics in an extending orogen' was developed $3 \mathrm{~km}$ east of his office at Harvard (Wernicke 1981, 2009), but I know of nothing to suggest that Haller ever viewed East Greenland tectonics in a pre-Atlantic drift framework.

McMaster was still a small university (1,000 undergraduates) at the time of Koch's 1964 lecture (Fig. 13), but one strongly committed to the natural sciences under Dean Henry G. Thode, who had measured and explained the fractionation of carbon, nitrogen and sulfur isotopes in nature and in the laboratory under the master, Harold Urey (Shaw et al. 2000). The Geology Department was flourishing and invited speakers included both advocates (Harry Hess) and adversaries (Frank Stehli) of continental drift, at a time when few departments had any inkling that a major scientific revolution was underway. McMaster sedimentologist Gerard V. (Gerry) Middleton, whose South African roots were otherwise well concealed, stated that Alex du Toit's geological comparison of South America with southern Africa could not be ignored (du Toit 1927, 1937; Martin 1961).

Lauge Koch's presentation on the Precambrian geology of Greenland was expected to be well attended. The large lecture theatre in Hamilton Hall was booked, with a reception afterwards. His lecture would be profusely illustrated with large-format aerial photographs taken with his own aircraft. He did not bring the photographs as overhead transparencies or $35 \mathrm{~mm}$ slides, but as glass-mounted $3^{1 / 4} \times 4^{1 / 4}$ inch $(83 \times 103 \mathrm{~mm})$ lantern slides, arranged in numbered boxes. There was only one projector with a carrier suitable for his oversize slides, an ancient arc lamp contraption the size of an expedition rucksack. The light beam was generated by heating carbon

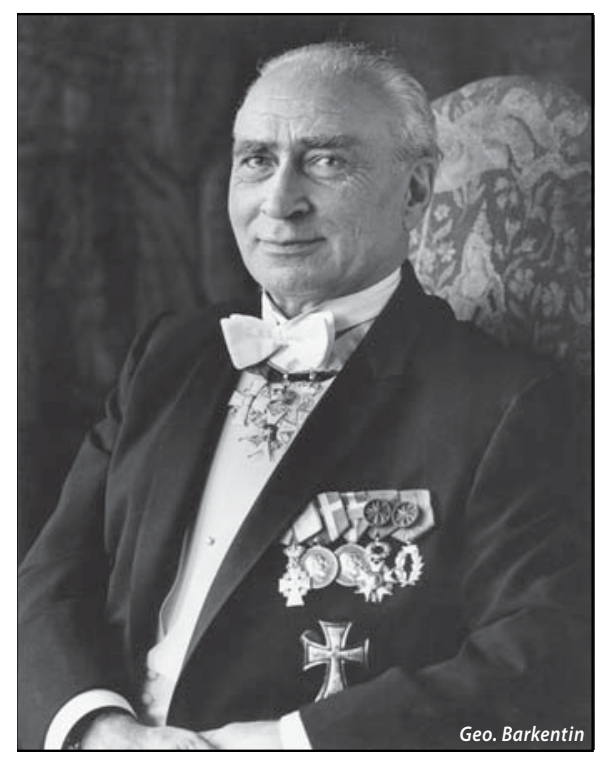

Figure 13. Lauge Koch in 1963, the year he received an honorary doctorate from McGill University and a year before his last lecture at McMaster University (photo courtesy of Koch Family through Peter R. Dawes).

rods to incandescence with an electric arc. Because of its noise, the projector was mounted in a sound-proof projection booth in the back of the lecture theatre. As an undergraduate, I was asked to run the projector, changing the slides as prompted by hand signals from Koch at the front of the hall. The hitch was that many of Koch's lantern slides were in vertical format, while the slide holder in the projector could only accommodate horizontals. However, the projector itself had two strong metal handles, one on each side, allowing the projectionist to lift the 20kilogram contraption off its mount, rotate the entire unit $90^{\circ}$ by hand and hold it. Problem solved, Koch's lecture began.

What hadn't been anticipated was that as Koch's talk wore on, formation by formation, the projector and its metal handles got hotter and hotter. It became ever more difficult to hold the projector unit steady for vertical slides while the handles burned into my palms. Every flinch caused the giant image on the screen to dance away from Koch's pointer, as he attempted to describe the stratigraphy of the bottomless Eleonore Bay Supergroup, bed-group by bed-group. Koch became more and more agitated: his hand signals were delivered first with flashing eyes, then exasperated gestures and finally shouts, but I could hear nothing. At length, the lecture mercifully ended and during the question period I slipped outside in search of snow for the palms of my hands. The blisters were still healing when I ran the Boston Marathon a month later.

A few days afterwards, I heard that Koch had become ill the morning after his Hamilton Hall lecture, and that his next scheduled appearance, at a meeting of The Arctic Circle in Ottawa, had been cancelled. After the field season, I read that Koch had died in Copenhagen over the summer. For nearly fifty years I lived under the assumption that Koch had suffered a stroke or heart attack that morning in Hamilton, perhaps brought on by the stress of the lecture. While writing this story, I learned that Koch returned to New York City, where his daughter lived, underwent surgery and was flown home to Copenhagen, but did not recover (Dawes 2012). On the nature of his illness I found but a single reference in English, that by the West Greenland ethnographer Klaus Georg Hansen, whose entry on Koch in the Encyclopedia of the Arctic (Hansen 2005) states that he died of cancer.

\section{ACKNOWLEDGEMENTS}

Detailed comments by Peter Dawes (Copenhagen) and Tom Frisch (Ottawa) led to many factual improvements. Dawes kindly also provided the portrait of Koch (Fig. 13). Randolph Corney helped digitize the old figures.

\section{REFERENCES}

Agassiz, L., 1842, The glacier theory and its recent progress: Edinburgh New Philosophical Journal, v. 33, no. 46, p. 217-283.

Bengaard, H.-J., 1992, Upper Proterozoic (Eleonore Bay Group) to Devonian, central fjord zone, East Greenland: Geological Survey of Greenland, Map scale 1:250,000.

Bengaard, H.-J., and Henriksen, N., 1986, Geological map of Greenland, 1:500,000, Peary Land, sheet 8: Geological Survey of Greenland, Copenhagen.

Birkelund, T., and Perch-Nielsen, K., 1976, Late Paleozoic - Mesozoic evolution of central East Greenland, in Escher, A., and Watt, W.S., eds., Geology of Greenland: Greenland Geological Sur- 
vey, Copenhagen, p. 302-339.

Bøggild, O.B., Bøgvad, R., Callisen, K., Frebold, H., Gry, H., Jessen, H., Madsen, V., Noe-Nygaard, A., Poulsen, C., Rosenkrantz, A., and Teichert, C., 1935, Remarks upon 'Lauge Koch: Geologie von Grönland, 1935’: Bulletin of the Geological Society of Denmark, v. 8, no. 5, p. 497-512 (also in Danish and German).

Boylan, P.J., 1998, Lyell and the dilemma of Quaternary glaciation, in Blundell, D.J., and Scott, A.C., eds., Lyell: the Past is the Key to the Present: Geological Society, London, Special Publication 143, p. 145-159.

Brooks, K., 2008, The new geological map of East Greenland: Geology Today, v. 24, p. 28-32, http://dx.doi.org/ 10.1111/j.1365-2451.2008.00648.x.

Brooks, K., 2009, The Caledonides of East Greenland-tales of the birth and death of oceans: Geology Today, v. 25, p. 94-99, http://dx.doi.org/ 10.1111/j.1365-2451.2009.00715.x.

Christie, R.L., Dawes, P.R., Frisch, T., Higgins, A.K., Hurst, J.M., Kerr, J.WM., and Peel, J.S., 1981, Geological evidence against major displacement in the Nares Strait: Nature, v. 291, p. 478-480, http://dx.doi.org/10.1038/291478a0.

Clack, J.A., 2002, Gaining Ground: The Origin and Evolution of Tetrapods: Indiana University Press, Bloomington, $369 \mathrm{p}$.

Cocks, L.R.M., and Torsvik, T.H., 2011, The Palaeozoic geography of Laurentia and western Laurussia: A stable craton with mobile margins: EarthScience Reviews, v. 106, p. 1-51, http://dx.doi.org/10.1016/j.earscirev. 2011.01.007.

Cowie, J.W., 1959, Lauge Koch's expeditions to east Greenland, 1926 to 1958: Polar Record, v. 9, no. 63, p. 547-552, http://dx.doi.org/10.1017/S00322474 00066729.

Cowie, J.W., and Adams, P.J., 1957, The geology of the Cambro-Ordovician rocks of central East Greenland, Part I: stratigraphy and structure: Meddelelser om Grønland, v. 153, no. 1, p. 1-193, 13 pl.

Dawes, P.R., 1976, Precambrian to Tertiary of northern Greenland, in Escher, A., and Watt, W.S., eds., Geology of Greenland: Greenland Geological Survey, Copenhagen, p. 248-303.

Dawes, P.R., 1997, The Proterozoic Thule Supergroup, Greenland and Canada: history, lithostratigraphy and development: Geology of Greenland Survey Bulletin 174, 150 p.

Dawes, P.R., 2004, Explanatory notes to the Geological map of Greenland, 1:500,000, Humboldt Gletscher, Sheet 6: Geological Survey of Greenland, Map Series 1, 48 p.

Dawes, P.R., 2006a, Explanatory notes to the Geological map of Greenland, 1:500,000, Thule, sheet 5: Geological Survey of Greenland, Map Series 2, $97 \mathrm{p}$.

Dawes, P.R., 2006b, Geological map of Greenland, 1:500,000, Thule, sheet 5: Geological Survey of Greenland, Copenhagen.

Dawes, P.R., 2009, Precambrian-Palaeozoic geology of Smith Sound, Canada and Greenland: key constraint to palaeogeographic reconstructions of northern Laurentia and the North Atlantic region: Terra Nova, v. 21, p. 1-13, http://dx.doi.org/10.1111/j.13653121.2008.00845.x.

Dawes, P.R., 2012, The Koch Family Papers Part 1: New Insight into the Life, Work and Aspirations of Greenland Geo-Explorer Lauge Koch (1892-1964): Geological Survey of Denmark and Greenland (GEUS), Copenhagen, $220 \mathrm{p}$.

Dawes, P.R., and Garde, A.A., 2004, Geological map of Greenland, 1:500,000, Humboldt Gletscher, sheet 6: Geological Survey of Greenland, Copenhagen.

Dawes, P.R., and Haller, J., 1979, Historical aspects in the geological development of northern Greenland. Part 1: New maps and photographs from the 2nd Thule Expedition 1916-1918 and the Bicentenary Jubilee Expedition 19201923: Meddelelser om Grønland, v. 200, no. 4, p. 1-38.

De Paor, D.G., Bradley, D.C., Eisenstadt, G., and Phillips, S.M., 1989, The Arctic Eurekan orogen: A most unusual fold-and-thrust belt: Geological Society of America Bulletin, v. 101, p. 952-967, http:/ /dx.doi.org/ 10.1130/0016-7606(1989)101 $<0952$ :TAEOAM>2.3.CO;2.

Denyszyn, S.W., Halls, H.C., Davis, D.W., and Evans, D.A.D., 2009, Paleomagnetism and $\mathrm{U}-\mathrm{Pb}$ geochronology of Franklin dykes in High Arctic Canada and Greenland: a revised age and paleomagnetic pole constraining block rotations in the Nares Strait region: Canadian Journal of Earth Sciences, v. 46, p. 689-705, http://dx.doi.org/10.1139/E09-042.

du Toit, A.L., 1927, A geological comparison of South America with South Africa: Carnegie Institution of Washington, Publication 381, 158 p.

du Toit, A.L., 1937, Our Wandering Continents: Hafner, New York, 366 p.
Dunbar, C.O., 1966, Memorial to Lauge Koch (1892-1964): Geological Society of America Bulletin, v. 77, p. 145-154, http://dx.doi.org/10.1130/00167606(1966)77[P145:MTLK]2.0.CO;2.

Escher, A., and Watt, W.S., eds., 1976, Geology of Greenland: Greenland Geological Survey, Copenhagen, 603 p.

Escher, J.C., 2001, Geological map of Greenland, 1:500,000, Kong Oscar Fjord, sheet 11: Geological Survey of Greenland, Copenhagen.

Frankel, H., 2012, The Continental Drift Controversy, vol. 2: Paleomagnetism and Confirmation of Drift: Cambridge University Press, Cambridge, 525 p.

Gilotti, J.A., and McClelland, W.C., 2008, Geometry, kinematics, and timing of extensional faulting in the Greenland Caledonides-A synthesis, in Higgins, A.K., Gilotti, J.A., and Smith, M.P., eds., The Greenland Caledonides: Evolution of the Northeast Margin of Laurentia: Geological Society of America Memoirs, v. 202, p. 251-271, http://dx.doi.org/10.1130/2008.1202( 10).

Haller, J., 1970, Tectonic map of East Greenland (1:500,000): an account of tectonism, plutonism, and volcanism in East Greenland: Meddelelser om Grønland, v. 171, no. 5, p. 1-286.

Haller, J., 1971, Geology of the East Greenland Caledonides: John Wiley Interscience, London, $413 \mathrm{p}$.

Hambrey, M.J., and Spencer, A.M., 1987, Late Precambrian glaciation of central East Greenland: Meddelelser om Grønland, Geoscience 19, 50 p.

Hansen, K.G., 2005, Koch, Lauge, in Nuttall, M., ed., Encyclopedia of the Arctic: Routledge, p. 1103-1105.

Hartz, E., 2000, Early syndepositional tectonics of East Greenland's Old Red Sandstone basin, in Friend, P.F., and Williams, B.P.J., eds., New Perspectives on the Old Red Sandstone: Geological Society, London, Special Publication 180 , p. $537-555$.

Hartz, E., and Andresen, A., 1995, Caledonian sole thrust of central East Greenland: A crustal-scale Devonian extensional detachment?: Geology, v. 23, p. 637-640, http://dx.doi.org/ 10.1130/0091-7613(1995)023 $<0637$ :CSTOCE >2.3.CO;2.

Hartz, E.H., Andresen, A., Hodges, K.V., and Martin, M.W., 2001, Syncontractional extension and exhumation of deep crustal rocks in the east Greenland Caledonides: Tectonics, v. 20, p. 58-77, http:/ /dx.doi.org/ 10.1029/2000TC900020. 
Hayes, D., 2003, Historical Atlas of the Arctic: Douglas \& McIntyre, Vancouver, $208 \mathrm{p}$.

Henriksen, N., 1989, Geological map of Greenland, 1:500,000, Nyeboe Land, sheet 7: Geological Survey of Greenland, Copenhagen.

Henriksen, N., 1997, Geological map of Greenland, 1:500,000, Dove Bugt, sheet 10: Geological Survey of Greenland, Copenhagen.

Henriksen, N., 2008, Geological History of Greenland: Four Billion Years of Earth Evolution: Geological Survey of Denmark and Greenland, Copenhagen, $272 \mathrm{p}$.

Henriksen, N., and Higgins, A.K., 2008, Caledonian orogen of East Greenland $70^{\circ} \mathrm{N}-82^{\circ} \mathrm{N}$ : Geological map at 1:1,000,000_Concepts and principles of compilation, in Higgins, A.K., Gilotti, J.A., and Smith, M.P., eds., The Greenland Caledonides: Evolution of the Northeast Margin of Laurentia: Geological Society of America Memoirs, v. 202, p. 345-368, http://dx.doi.org/ 10.1130/2008.1202(14).

Higgins, A.K., Gilotti, J.A., and Smith, M.P., 2008, The Greenland Caledonides: Evolution of the Northeast Margin of Laurentia: Geological Society of America Memoirs, v. 202, 368 p.

Hobbs, W.H., 1936, Geologie von Grönland by Lauge Koch (Review): The Journal of Geology, v. 44, p. 758-760, http://dx.doi.org/10.1086/624477.

Jacoby, W.R., 2001, Translation of Die Entstehung der Kontinente Dr Alfred Wegener: Journal of Geodynamics, v. 32, p. 29-63.

Jarvik, E., 1961, Devonian vertebrates, in Raasch, G.O., ed., Geology of the Arctic, vol. I: University of Toronto Press, p. 197-204.

Jepsen, H. F., 1971, The Precambrian, Eocambrian and Early Paleozoic stratigraphy of the Jørgen Brønlund Fjord area, Peary Land, North Greenland: Meddelelser om Grønland, v. 192, no. 2, p. 1-42.

Katz, H.R., 1961, Late Precambrian to Cambrian stratigraphy in East Greenland, in Raasch, G.O., ed., Geology of the Artic, Proceedings of the First International Symposium on Arctic Geology (Calgary, AB, January 11-13, 1960), v. 1: University of Toronto Press, p. 299-328.

Koch, L., 1919, Plan for Jubilaeumsekspeditionen Nord om Grønland: Geografisk Tidsskrift, v. 25, p. 226-228.

Koch, L., 1920, Stratigraphy of Northwest
Greenland: Bulletin of the Geological Society of Denmark, v. 5, no. 17, p. 1-78.

Koch, L., 1921, Geological observations, in Rasmussen, K., ed., Greenland by the Polar Sea: the Story of the Thule Expedition from Melville Bay to Cape Morris Jessup, translated from the Danish by Asta and Rowland Kenney: Frederick A. Stokes, New York, p. 301-311.

Koch, L., 1922, Note to the maps of Melville Bay from Wilcox Point to Cape York and of North Greenland from $81^{\circ}-83^{\circ} 35^{\prime} \mathrm{N}, 38^{\circ}-56^{\circ} \mathrm{W}$ : Meddelelser om Grønland, v. 64, no. 2, p. 77-88.

Koch, L., 1923a, Preliminary report on the results of the Danish Bicentenary Expedition to North Greenland: The Geographical Journal, v. 62, p. 103-117, http://dx.doi.org/10.2307/1781336.

Koch, L., 1923b, Preliminary report upon the geology of Peary Land, Arctic Greenland: American Journal of Science, v. 5, p. 189-199, http://dx.doi.org/10.2475/ajs.s55.27.189.

Koch, L., 1923c, Some new features in the physiography and geology of Greenland: The Journal of Geology, v. 31, p. 42-65, http://dx.doi.org/10.1086/622979.

Koch, L., 1924, North of Greenland: The Geographical Journal, v. 64, p. 6-21, http:/ /dx.doi.org/10.2307/1781364.

Koch, L., 1925a, The question of Peary Channel: Geographical Review, v. 15, p. 643-649, http://dx.doi.org/10.2307/208628.

Koch, L., 1925b, The geology of North Greenland: American Journal of Science, v. 9, p. 271-285, http://dx.doi.org/10.2475/ajs.s59.52.271.

Koch, L., 1927, Report on the Danish Bicentenary Jubilee Expedition North of Greenland, 1920-23: Meddelelser om Grønland, v. 70, p. 1-232.

Koch, L., 1928, Preliminary statement of the stratigraphy of East Greenland: American Journal of Science, v. 15, p. 346-349, http:/ /dx.doi.org/ 10.2475/ajs.s5-15.88.346.

Koch, L., 1929a, The geology of the south coast of Washington Land: Meddelelser om Grønland, v. 73, p. 1-39.

Koch, L., 1929b, The geology of East Greenland: Meddelelser om Grønland, v. 73, pt. II, p. 1-204.

Koch, L., 1929c, Stratigraphy of Greenland: Meddelelser om Grønland, v. 73, pt. II, p. 205-320.

Koch, L., 1930, Report on the geological expedition to East Greenland 1926-27: Meddelelser om Grønland, v. 76, p. 225-282.

Koch L., 1932, Map of North Greenland, scale 1:300 000, surveyed by Lauge Koch in the years 1917-1923, 19 sheets: Geodetic Institute, Copenhagen.

Koch, L., 1933, The geology of Inglefield Land: Meddelelser om Grønland, v. 73, pt. I, p. 1-38.

Koch, L., 1935, Geologie von Grönland: Geologie der Erde, Berlin, 159 p.

Koch, L., 1940, Survey of North Greenland: Meddelelser om Grønland, v. 130, p. 1-364.

Koch, L., 1955, Report on the expeditions to central East Greenland, 1926-39, conducted by Lauge Koch: Meddelelser om Grønland, v. 143, p. 1-642.

Koch, L., 1961, Journeys and expeditions to Greenland in the years 1913-1959: a summary, in Raasch, G.O., ed., Geology of the Artic, Proceedings of the First International Symposium on Arctic Geology (Calgary, AB, January 11-13, 1960), v. 1: University of Toronto Press, p. 293-298.

Koch, L., 1963, Greenland's morphological and geological features and their problems: Experientia (Birkhäuser Verlag, Basel, Switzerland), v. 19, no. 6, p. 273-281.

Koch, L., and Haller, J., 1971, Geological map of East Greenland $72^{\circ} \mathrm{N}-76^{\circ} \mathrm{N}$ Lat. (1:250,000 scale): Meddelelser om Grønland, v. 183, p. 1-26, + 13 maps.

Köppen, V., and Wegener, A., 1924, Die Klimate der geologischen Vorzeit: Borntraeger, Berlin, 255 p.

Larsen, P.-H., and Bengaard, H.-J., 1991, Devonian basin initiation in East Greenland: a result of sinistral wrench faulting and Caldeonian extensional collapse: Journal of the Geological Society, v. 148, p. 355-368, http://dx.doi.org/10.1144/gsigs.148.2. 0355.

Larsen, P.-H., Olsen, H., and Clack, J., 2008, The Devonian basin in East Greenland-Review of basin evolution and vertebrate assemblages, in Higgins, A.K., Gilotti, J.A., and Smith, M.P., eds., The Greenland Caledonides: Evolution of the Northeast Margin of Laurentia: Geological Society of America Memoirs, v. 202, p. 273-292, http://dx.doi.org/10.1130/2008.1202( 11).

Lyberis, N., and Manby, G., 1999, The Eurekan deformation of north and eastern North Greenland: Polarforschung, v. 69, p. 95-106.

Lyell, C., 1863, The Geological Evidences 
of the Antiquity of Man: John Murray, London, 551 p.

Lyell, C., 1865, Elements of Geology, 6th enlarged ed.: John Murray, London, $794 \mathrm{p}$.

Markham, C.R., 1921, The Lands of Silence: A History of Arctic and Antarctic Exploration: Cambridge University Press, 628 p.

Martin, H., 1961, The hypothesis of continental drift in the light of recent advances of geological knowledge in Brazil and in South West Africa: 7th Alex. du Toit Memorial Lecture, Geological Society of South Africa, Annexures, v. 64, p. 1-47.

Mathiassen, T., 1934, Knud Rasmussen's sledge expeditions and the founding of the Thule trading station: Geografisk Tidsskrift, v. 37, p. 17-30.

McClay, K.R., Norton, M.G., Coney, P., and Davis, G.H., 1986, Collapse of the Caledonian orogen and the Old Red Sandstone: Nature, v. 323, p. 147-149, http://dx.doi.org/10.1038/323147a0.

Miall, A.D., 1983, The Nares Strait problem: A re-evaluation of the geological evidence in terms of a diffuse oblique-slip plate boundary between Greenland and the Canadian Arctic Islands: Tectonophysics, v. 100, p. 227-239, http:/ /dx.doi.org/ 10.1016/0040-1951(83)90189-0.

Mills, W.J., 2003, Exploring Polar Frontiers: A Historical Encyclopedia, v. 1: ABCCLIO, 797 p.

Müller, F., 1964, Lauge Koch (1892-1964): Arctic, v. 17, p. 290-292.

Noe-Nygaard, A., 1976, Tertiary igneous rocks between Shannon and Scoresby Sund, East Greenland, in Escher, A., and Watt, W.S., eds., Geology of Greenland: Greenland Geological Survey, Copenhagen, p. 386-402.

Okulitch, A.V., Dawes, P.R., Higgins, A.K., Soper, N.J., and Christie, R.L., 1990, Towards a Nares Strait solution: Structural studies on southeastern Ellesmere Island and northwestern Greenland: Marine Geology, v. 93, p. 369-384, http://dx.doi.org/ 10.1016/0025-3227(90)90093-Y.

Peary, R.E., 1893, The great white journey across Greenland, in Diebitsch-Peary, J., ed., My Arctic Journal: a Year Among Ice-fields and Eskimos: Contemporary, New York, p. 221-241.

Peary, R.E., 1903, Four year's Arctic exploration, 1898-1902: The Geographical Journal, v. 22, p. 646-668, http://dx.doi.org/10.2307/1775093.

Rasmussen, K., 1915, Report of the First Thule Expedition, 1912: Meddelelser om Grønland, v. 51, no. 8, p. 1-141.
Rasmussen, K., 1921, Greenland by the Polar Sea: the Story of the Thule Expedition from Melville Bay to Cape Morris Jessup, translated from the Danish by Asta and Rowland Kenney: Frederick A. Stokes, New York, 327 p.

Rasmussen, K., 1927, Report on the II. Thule-Expedition for the exploration of Greenland from Melville Bugt to De Long Fjord, 1916-1918: Meddelelser om Grønland, v. 65, no. 14, p. 1-180 p.

Ries, C., 2002, Lauge Koch and the mapping of North East Greenland: Tradition and modernity in Danish Arctic Research, 1920-1940, in Bravo, M., and Sörlin, S., eds., Narrating the Arctic: A Cultural History of Nordic Scientific Practices: Science History Publications/USA, Canton, Massachusetts, p. 199-231.

Rink, H., 1853, On the large continental ice of Greenland, and the origin of icebergs in the Arctic seas: Journal of the Royal Geographical Society of London, v. 23, p. 145-154, http://dx.doi.org/10.2307/1797957.

Shaw, D.M., Epstein, S., and Hayes, J.M., 2000, Memorial to Henry G. Thode 1910-1997: Geological Society of America Memorials, v. 31, p. 11-15.

Smith, M.P., and Rasmussen, J.A., 2008, Cambro-Silurian development of the Laurentian margin of the Iapetus Ocean in Greenland and related areas, in Higgins, A.K., Gilotti, J.A., and Smith, M.P., eds., The Greenland Caledonides: Evolution of the Northeast Margin of Laurentia: Geological Society of America, Memoirs, v. 202, p. 137-167, http:/ /dx.doi.org/ 10.1130/2008.1202(06).

Sønderholm, M., and Tirsgaard, H., 1993, Lithostratigraphic framework of the Upper Proterozoic Eleonore Bay Supergroup of East and North-East Greenland: Geological Survey of Greenland, Bulletin 167, 38 p.

Sønderholm, M., Frederiksen, K.S., Smith, M.P., and Tirsgaard, H., 2008, Neoproterozoic sedimentary basins with glacigenic deposits of the East Greenland Caledonides, in Higgins, A.K., Gilotti, J.A., and Smith, M.P., eds., The Greenland Caledonides: Evolution of the Northeast Margin of Laurentia: Geological Society of America Memoirs, v. 202, p. 99-136,

http://dx.doi.org/ 10.1130/2008.1202(05).

Taylor, F.B., 1910, Bearing of the Teriary mountain belt in the origin of the earth's plan: Geological Society of America Bulletin, v. 21, p. 179-226. Tessensohn, F., Jackson, R.H., and Reid,
I.D., 2006, The tectonic evolution of Nares Strait: implications of new data: Polarforschung, v. 74, no. 1-3, p. 191-198.

Tessensohn, F., von Gosen, W., Piepjohn, K., Saalmann, K., and Mayr, U., 2008, Nares transform motion and Eurekan compression along the northeast coast of Ellesmere Island, in Mayr, U., ed., Geology of northeast Ellesmere Island adjacent to Kane Basin and Kennedy Channel: Geological Survey of Canada, Bulletin 592, p. 227-243.

Tirsgaard, H., and Sønderholm, M., 1997, Lithostratigraphy, sedimentary evolution and sequence stratigraphy of the Upper Proterozoic Lyell Land Group (Eleonore Bay Supergroup) of East and North-East Greenland: Geological Survey of Denmark and Greenland, Bulletin 178, 60 p.

Torsvik, T.H., 1998, Palaeozoic palaeogeography: A North Atlantic viewpoint: Geologiska Föreningens Förhandlingar, v. 120, no. 2, p. 109-118.

Upton, B.G.J., Rämö, O.T., Heaman, L.M., Blichert-Toft, J., Kalsbeek, F., Barry, T.L., and Jepsen, H.F., 2005, The Mesoproterozoic Zig-Zag Dal basalts and associated intrusions of eastern North Greenland: mantle plume-lithosphere interaction: Contributions to Mineralogy and Petrology, v. 149, p. 40-56, http://dx.doi.org/ 10.1007/s00410-004-0634-7.

von Gosen, W., Piepjohn, K., Tessensohn, F., and Saalmann, K., 2008, Eurekan fault tectonics on Judge Daly Promontory and their implications for displacements along Nares Strait, in Mayr, U., ed., Geology of northeast Ellesmere Island adjacent to Kane Basin and Kennedy Channel: Geological Survey of Canada, Bulletin 592, p. 325-346.

Wegener, A., 1924, The Origin of Continents and Oceans (English translation by J. G. A. Skerl of the 1922 German 3rd ed.): Dutton, New York, 212 p.

Wernicke, B., 1981, Low-angle normal faults in the Basin and Range Province: nappe tectonics in an extending orogen: Nature, v. 291, p. 645-648, http://dx.doi.org/10.1038/291645a0.

Wernicke, B., 2009, The detachment era (1977-1982) and its role in revolutionizing continental tectonics, in Ring, U., and Wernicke, B., eds., Extending a Continent: Architecture, Rheology and Heat Budget: Geological Society, London, Special Publication 321, p. 1-8. 